\title{
Application of Question Teaching Method in the Art and Design Teaching of Universities
}

\author{
Xiangdong Dou \\ College of Fine Arts, Shaanxi Normal University, Xi'an, China \\ Email: guicaitang@163.com
}

Received 12 October 2015; accepted 20 November 2015; published 23 November 2015

Copyright (C) 2015 by author and Scientific Research Publishing Inc.

This work is licensed under the Creative Commons Attribution International License (CC BY). http://creativecommons.org/licenses/by/4.0/

c) (i) Open Access

\begin{abstract}
Question teaching method can change the bad state of students in learning, from passive learning to active learning, refuse mechanical imitation and enhance their sense of innovation. This approach can help the cultivation of innovative talents in major of art and design and improve their ability of innovation. Question teaching mode is used primarily in art and design teaching activities, e.g. questions design and contextual design, and other links all cannot be done without this important method.
\end{abstract}

Keywords

Question Teaching, Efficient Art Design, Talents Cultivation

\section{Introduction}

Question teaching mode was produced in the United States in the fifties of last century. It first appeared in the field of medical education, and later because of the ideal teaching effect, it was gradually applied to other fields. In the 1980's, our country began to introduce this method and now it has become a common teaching method.

However, what is the "question teaching"? In fact, it means that the teachers take teaching objectives as the basis, and according to the specific requirements of teaching, select some problems that can reflect general relations, properties and methods, to create a certain situation, so as to make students have a better learning enthusiasm. Teachers can use the rhythm control to help students exercise their deficiencies in the process of seeking answers to questions, and then to help students develop good thinking skills. This method can ensure that students maintain high learning passion and learning initiative, and can help students to better get access to knowledge and creativity. Generally speaking, question teaching mainly has the following important features: according to the connotation of question teaching, setting problem situation, raising questions, solving problems, and thus helping students enhance their ability. 
According to the development of this teaching method in China, the application of question teaching mode is relatively usual in the foundation education, especially in early childhood education and elementary education. Such an approach can improve the learning atmosphere, make students have stronger passion and be interested in learning and help students develop their initiative [1]. Just for this, this method is welcomed by the industry of education, but at the university level, due to the impact of many aspects such as system, personnel structure, curriculum setting, teaching form evaluation criteria, and so on, this method is not really promoted and applied. According to the application effect of question teaching mode and the inherent shortage of efficient art and design, author believes that this teaching mode can play a good role in art and design teaching of domestic colleges and universities.

\section{Analysis on Current Situation of Art and Design Education}

Since Bauhaus modern industrial design education system is recognized and used world widely, art and design education has been more and more important gradually for all countries, and got more and more related to the economic strength of a country. In recent years, our domestic market economy has been prosperous, the industry of art and design has gradually become the popular content in the market, which has good promotion for the development of art and design education. Until now, in our country more than a thousand colleges and universities set up the major of art and design, with a large scale and a high speed, which is unusual. The education of art and design should not be developed overnight, and it should have a process of gradual improvement, step by step and little by little. Those education methods in excessive pursuit of speed and quantity but in ignorance of the law of science, will lead to a lot of problems in education. According to our domestic art and design, author found the teaching of art and design is of unscientific structure, the course content does not meet the needs of the times, and the teaching method is too outdated [2].

At the end of 1980s, our country began to introduce art education system, and from that we always insist on the traditional form of "master training apprentice" in art and design. This teaching form focuses on experience, of which teachers are dominant in the entire teaching activities and students are passive who learn simply according to their teacher's step, without initiative and creativity. When this passive learning becomes a habit, students will be late for class, leave early, give a sloppy and bad homework, copy others' homework, and have poor design ability and so on. Our domestic teachers often believe that students are not as diligent as before and their learning ability gets worse year by year. Current students are not diligent or clever, really? No, it is not because of students but the conservative traditional teaching methods of this teaching mode that has been unable to meet the students' needs.

We all know that art and design teaching are significantly different from other subjects, and it focuses on the practice to help students improve their practical ability. But too much emphasis on professional skills training, leads to the ignorance of students' research ability and creative ability in art and design. The relative survey of headhunting companies shows that those talents who both have good professional ability and have good sense of innovation in art and design are most popular in the talents competition. So, how to help the students of art and design improve their ability of innovation and to transform single skill training gradually becomes most concerned for the people in education [3]. In combination with his teaching experience in art and design, author considers that the introduction of efficient question teaching mode into the major of art and design in colleges and universities will help students change their attitude from passive learning to active learning, not simply imitate, and improve their sense of innovation and professional literacy. This change on teaching will be able to help students develop their professional creative thinking, so as to satisfy the market needs for professionals. In the following, the author makes a simple analysis is on the application of question teaching mode in art and design, based on his professional experience.

\section{The Application Design of Question Teaching Mode in Art and Design Teaching}

To make effect of question teaching mode, we should take teachers as the focus and the core. If teachers raise the proper questions at the proper time during their teaching and guide students to choose a proper solution, the question teaching mode will have a significant effect on the teaching in art and design. Teachers should use this method to help students develop their habit to actively study problems, and should create appropriate scene and design scientific and rational problems to make these problems in line with the needs of practical teaching, so that we can truly help students think and consider their study contents. In fact, the common assessment criteria 
for the teachers of art and design is that the teachers should have a good technical and practical ability and must help students learn the skills of hand-painting performance in the classroom. Once they have such ability, the teachers will be excellent. And the development of students in the future and their innovation ability seems to have nothing to do with the teacher. But the question teaching mode requires teachers should have a good professional skill and thoroughly understand the teaching contents, to fully present the learning contents and make the courses as scientific, vivid and lively as possible. Selection of each question by teachers should have strong significance of realistic practice, and it must be developed for innovation ability.

We should know, the question teaching mode is gradually concerned by the education sector, but now there is no a unified standard of question teaching mode, because question teaching mode is not a fixed method that can be used directly and indiscriminately. For different subjects and different learning objectives, teaching law is different and variable. Even for the same major, the method is also different for the specific needs and teachers and curriculum arrangement. So question teaching mode should be used flexibly as a new method, and teachers should make practical application according to the actual needs and in combination with the features of art and design, and there are three types of operation as the following:

\subsection{The Application of Question Teaching Mode That Teachers Directly Raise Questions}

The paper has been said before, the key of question teaching is to ask questions and figure them out. The scientificity of the question design itself directly decides the teaching effect of teachers. Whether students have innovation ability and creativity is closely related to daily study. If there is no clear purpose in question, or the question is not summary or lack of inquiry, it will produce no influence on students' innovation ability, and even it may result in the non-realization of talent cultivation target and the suspicion of students on learning value and significance. They may ignore objective laws, imagine the development state of things subjectively and be not able to observe. It needs teachers to learn and research persistently in the teaching to raise a practically valuable question that can increase students' inquiry ability.

For example, when teachers carry out design sketch teaching, the question teaching mode requires teachers to clear two points before the beginning of class. First is design. Teachers should help students figure out what is design sketch and the difference from traditional painting sketch. Then they should help students to clear the purpose of learning design sketch and the significance of this course. After clearing these two points, teachers can teach students how to learn sketch. In general, teachers often tell students answers directly, and sometimes they do not even consider whether students understand it or not and they directly enter into the subject. In the process of teaching, some teachers simply told students their story, and did not leave opportunities for students to explore and practice, which is not conducive to the growth of students [4].

Obviously, the traditional teaching mode is only the mechanical reappearing of knowledge. Teacher demonstration is its main teaching approach, but this teaching mode is not conducive to the cultivation of students' divergent thinking, and may frustrate students' enthusiasm quickly. To the extent that students only can copy mechanically and apply indiscriminately. This teaching and learning relationship between teachers and students is not scientific. In a reasonable teacher-student relationship, teachers should be in a leading position, rather than forcing students to learn. Students should be in a principal position, rather than a wooden man that could not think or express. If we use this stale teaching mode, students' thinking could be completely restricted by the idea of teachers and they could not give an independent opinion and advice.

\subsection{The Application of Teachers' Problem-Hiding Design Subject and Students' Active Discovery Teaching Mode}

According to the above analysis it is not difficult to find that the teachers' direct questioning teaching mode mainly is not applicable for art and design teaching, for the art and design stresses practice. Its effect can be maximized in the theory teaching, but it is not good for students to answer questions in art and design class all the time. Therefore, the teachers' direct questioning teaching mode cannot meet the teaching needs of art and design. Teachers should not be confined to ask questions in problem arrangement, but they should help student transit to relative difficult points. Teachers should guide student to think problems and find solutions with students. In this process, teachers play a supporting role.

In the application of question mode, teachers should arrange questions according to specific teaching content. For example, teachers could place a group of different terrines on a still life table at will and ask students to 
choose several for sketching. In this choosing process, they participate in two important links, form analysis and form reconstruction. Teachers could hide the key points in subject design and give students an overall suggestion. Students need to find out how to disassemble, extract and recombine forms by themselves. Throughout the course, students need to follow their own feelings and teachers should not reveal the result, or tell students how to sketch or modify students' works. However, students' learning by themselves does not mean to let student alone. Students' knowledge is relative incomplete, so it is difficult for them to acquire knowledge all by themselves. Therefore, teachers need to create good pondering space for students, help them find problems and guide students to find the solutions to the problems in a cooperative attitude.

In fact, students will not copy mechanically when they enter into the students' active problem discovery teaching mode. Most of students could use what they learned to explore, research, judge and design all kinds of object structures and forms through a variety of resources on the Internet and complete their works independently. In the past, teacher needs to repeat explanation. But now, students could explore problems all by themselves. Seen from quality of work, the quality of work are much better by using new teaching mode. This learning mode could help students play their subjective initiative, carry our research proactively and thus improve their creative abilities and cognitive abilities.

\subsection{The Application of Question Teaching Mode That Students Explore Independently, Raise Questions and Come up with Solutions}

"If we say teaching mode that domestic education insists and pursues faces the past and focuses on knowledgetransference, innovative education is a new educational paradigm that faces the future and regards promoting students' development and cultivating innovative talents as fundamental value.” For talent cultivation, the most important part is to cultivate innovative thinking. While the most important part in innovative thinking is to find out problems, ask questions, analyze problems as well as solve them independently. Many educational cases show the question teaching mode that students explore independently, put forward doubts and actively find the solutions is an important model to improve students' innovative ability. On this occasion, students remain the state of autonomous learning [5]. They can not only consolidate knowledge that they have learnt, but also finish tasks and assignments prescribed by teachers independently or with teamwork. In fact, it's the extension and expansion of teaching. However, to acquire fully mature and autonomous inquiry ability, students need to be guided by complete process of problem: the teacher puts forward questions and students actively look for the answer, soon afterwards, students find problems and actively explore by themselves. This process is not simple and the links are connected. When teaching, if teachers cannot guide the students, help them to find out problems and develop good habits, it is impossible for students to find out problems directly and solve them. Therefore, compared with traditional teaching mode, the role of teachers hasn't been weakened, but become more important.

\section{Conclusion}

The goal of art and design education is to cultivate professional design talents for the society. Organically applying the question teaching mode to the teaching of art and design specialty can improve students' comprehensive strength and innovative ability. Question teaching method can change students' bad condition in learning, turn passive learning into active learning, refuse mechanical imitation as well as enhance their consciousness of innovation. The method can help art and design specialty to cultivate innovative talents and improve students' innovative ability. Question teaching mode is mainly used in teaching activities of art and design specialty. For example, question design and situation design can't do without this kind of important method. Therefore, every educator should seriously consider how to choose suitable teaching method according to the characteristics of art and design education.

\section{References}

[1] Zhu, Y.H. (2010) Investigation on Condition of Employment Demand of Art and Design Specialty and Suggestion on Talent Cultivation. Consume Guide, 61, 366.

[2] Yu, G.R. (2011) Looking the Art and Design Education of Comprehensive University from Employment Situation of the Graduates. Journal of Zhejiang Textile \& Fashion Vocational College, 10, 169. 
[3] Pan, F. (2012) Discussion on Teaching and Learning of Sketch Course in Art and Design Specialty. Contemporary Art. 36.

[4] Liu, C.Y. (2013) Discussion on Elaboration of Course Assessment of Art and Design Specialty in Higher Vocational Education. Vocational Technology, 13, 568.

[5] Hu, H.X. and Fan, H.B. (2009) Analysis on the Function of Multimedia Technology in Art and Design Teaching. Times Literary (Second Half), 16, 128. 